Jorge S. Reis-Filho • Pete T. Simpson • Albino Martins •

Ana Preto - Fátima Gärtner · Fernando C. Schmitt

Distribution of $\mathrm{p} 63$, cytokeratins $5 / 6$

\title{
and cytokeratin 14 in 51 normal and 400 neoplastic human tissue samples using TARP-4 multi-tumor tissue microarray
}

Received: 7 March 2003 / Accepted: 15 May 2003 / Published online: 16 July 2003

(C) Springer-Verlag 2003

\begin{abstract}
CK) 5/6 and CK 14 have been employed in diagnostic pathology as markers of basal, squamous and myoepithelial differentiation in several types of human neoplasms; however, there is scant data on the concurrent expression of these markers in large series of human neoplasms. We analyzed the distribution of these three immunohistochemical markers in 51 normal human tissue samples, 350 carcinomas, 25 malignant melanomas (MMs), and 25 glioblastomas using three serial sections of tissue array research program (TARP)-4 multi-tumor tissue microarray. Also, we performed double immunostainings to characterize the differential distribution of p63/CK 5/6 and p63/CK 14 in normal breast, salivary gland and skin. p63, CK 5/6 and CK 14 were expressed in basal cells of the prostate and respiratory epithelia and in breast and bronchial myoepithelial cells. p63 was also expressed in cytotrophoblast cells of human placenta and in scattered cells of lymph node germinal center. CK 5/6 and CK 14 also stained the cytoplasm of basal cells of esophageal stratified squamous epithelium and transitional epithelial cells of the bladder. No mesenchymal, neural, endothelial, smooth muscle or adipose cells were stained by any of the markers. p63, CK 5/6, and CK 14 were respectively expressed in $92.6 \%, 75.0 \%$, and $52.9 \%$ of the squamous cell carcinomas of the lung, $10.2 \%, 20.0 \%$, and $7.4 \%$ of the ductal carcinomas of the breast, $12.9 \%, 34.4 \%$, and
\end{abstract}

J. S. Reis-Filho · P. T. Simpson

The Breakthrough Toby Robins Breast Cancer Research Centre, Institute of Cancer Research,

London, UK

J. S. Reis-Filho · A. Martins

Life and Health Sciences Research Institute,

School of Health Sciences, University of Minho, Braga, Portugal

A. Preto · F. Gärtner · F. C. Schmitt $(\bowtie)$

IPATIMUP - Institute of Molecular Pathology and Immunology, University of Porto, R. Roberto Frias, S/N, 4200 Porto, Portugal e-mail: Fernando.Schmitt@ipatimup.pt

F. C. Schmitt

Medical Faculty, University of Porto, Porto, Portugal
$11.8 \%$ of the serous and $25.0 \%, 0 \%$, and $0 \%$ of the endometrioid carcinomas of the ovary. Lung, prostate and colonic adenocarcinomas, as well as MMs and glioblastomas were only rarely decorated by one of the markers. Only matched samples of 16 squamous cell carcinomas and two ductal carcinomas of the breast co-expressed these three markers. In double immunostainings, p63-CK $5 / 6$, as well as p63-CK 14 were co-expressed by basal/ myoepithelial cells of the salivary glands and basal cells of the epidermis. Our results demonstrate that p63, CK 5/ 6 and CK 14 may be used together in immunohistochemical panels to characterize squamous differentiation in poorly differentiated carcinomas or carcinomas of unknown origin.

Keywords Tissue microarray - Immunohistochemisty • Double immunostaining - Squamous cell carcinoma . Myoepithelial cell

\section{Introduction}

Cytokeratin (CK) is one of the three types of intermediate filaments that constitute the cytoskeleton of epithelial mammalian cells [7, 26]. At least 20 different keratin genes located either on chromosome 12 or 17 have been described [7, 38]. Each of these genes encodes specific keratin subunits, which may be classified as low- or highmolecular-weight CKs and as acidic or basic forms, based on their isoelectric points [7, 26]. Type-I CKs are small, acidic and encoded by genes located on chromosome 17, whereas type-II CKs are large, basic, and encoded by genes on chromosome 12 [7, 26, 38]. In epithelial cells, keratin filaments are composed of one type-I and one type-II CK [7, 26]. Different keratin isoforms are differentially expressed during development and differentiation and vary in different types of epithelia $[2,6,7,8$, $9,13,28,38,40,41,42]$. Several lines of evidence support that when an epithelial cell undergoes malignant transformation, it usually harbors a constant keratin 
profile, and this profile might serve to recognize different types of carcinomas $[2,6,7,8,9,13,28,38,40]$.

CK 5 and CK 14, also known as basal-type CKs, are consistently expressed in basal cells of multilayered epithelia, myoepithelial cells of the breast, salivary and sweat glands, Hassall's corpuscles of the thymus, parathyroid glands, hair follicle's outer root sheath, sebaceous glands and mesothelial cells $[2,6,7,8,9,13,42]$. CK 6 is a type-II CK expressed in filiform papillae of the tongue, oral and esophageal epithelia, the outer root sheath of the hair follicle and occasional glandular cells, but not in the breast [7]. CK 6 is only expressed in the epidermis of the palms and soles, or when it has undergone hyperplasia [7].

p63 is a nuclear transcription factor that harbors a high homology with p53 [10, 22, 32]. Its gene is located on $3 q 27$ and encodes at least six different isoforms that may be classified in two discrete groups: transactivating p63 (TA-p63) isoforms, which may bind to p53-reporter genes and activate their transcription and dominant negative $\mathrm{p} 63$ $(\Delta \mathrm{N}-\mathrm{p} 63)$ isoforms, which lack the transactivating $\mathrm{N}$ terminal region and can bind to canonical DNA-binding sites but cannot transactivate these genes [10, 22, 32]. We $[32,33,34,35,36,37]$ and others $[1,5,10,11,12,19,22$, $24,27,29,30,31,39,43,44,46,47]$ have described that p63 isoforms recognized by the antibody 4A4 are consistently expressed in the nuclei of basal cells of several types of multilayered epithelia and that $\Delta \mathrm{N}-\mathrm{p} 63$ isoforms are preferentially expressed in these cells. Dominant-negative p63 isoforms play an important role in the maintenance of basal cell populations, owing to their ability to overcome p53-driven cell cycle arrest and apoptosis [11, 19, 22, 24, 32, 47]. p63 is also consistently expressed by myoepithelial cells of the breast, salivary, bronchial and sweat glands $[1,5,10,11,12,19,22,24$, $27,30,31,32,33,34,35,36,37]$. Interestingly, p63 knockout mouse models have shown that the expression of p63 is of utmost importance for the correct differentiation of several types of multilayered epithelia $[22,27$, 47] and that p63 may promote the transcription of genes associated with terminal epithelial differentiation $[10,22$, 24, 47].

Multi-tumor tissue microarrays (TMAs) have proven to be very powerful tools for several purposes, including prognostic studies using immunohistochemical or in situ hybridization techniques, as well as the validation of results obtained from cDNA array experiments $[3,4,11$, $15,16,20,25,48]$. However, there are limited data on TMAs for the evaluation of the distribution of antibodies that might be used as diagnostic markers in surgical pathology practice. As p63, CK 5/6 and CK 14 show a similar distribution in several types of tissues $[2,6,8,9$, $11,13,19,24,28,32,33,34,35,37,38,43,47]$, our goals were: (i) to describe the expression of p63, CKs $5 / 6$ and CK 14 in 51 normal tissue samples and in 350 epithelial neoplasms, 25 melanomas and 25 glioblastomas using three serial sections of tissue array research program (TARP)-4 multi-tumor TMA; (ii) to determine which types of human tumors co-express these markers; and (iii) to evaluate the impact of these markers in surgical pathology practice. We also performed double-immunostainings for $\mathrm{p} 63 / \mathrm{CKs} 5 / 6$ and p63/CK 14 to demonstrate the concurrent expression of these proteins in normal mammary and salivary gland myoepithelial cells, as well as in basal keratinocytes.

\section{Materials and methods}

Tissue microarray

TARP-4 multi-tumor TMA slides were obtained from the Cooperative Human Tissue Network under the TARP of The National Cancer Institute, The National Institutes of Health, Bethesda, MD, USA. Briefly, this multi-tumor TMA is composed of 0.6-mm samples of normal tissue $[n=51$ : adrenal $(n=2)$, bladder $(n=2)$, bone marrow $(n=1)$, breast $(n=5)$, cerebellum $(n=1)$, cerebrum $(n=2)$, colon $(n=2)$, esophagus $(n=2)$, heart $(n=1)$, kidney ( 1 cortex and 1 medulla), liver $(n=3)$, lung $(n=3)$, lymph node $(n=2)$, mesothelium $(n=2)$, muscle $(n=1)$, ovary $(n=2)$, pancreas $(n=1)$, peripheral nerve $(n=1)$, placenta $(n=1)$, prostate $(n=2)$, salivary gland $(n=1)$, skin $(n=2)$, small bowel $(n=2)$, spleen $(n=2)$, stomach $(n=1)$, testis $(n=1)$, thyroid $(n=1)$, tongue $(n=1)$, uterus ( 1 endometrium and 1 myometrium)], breast cancer $(n=75)$, colon cancer $(n=75)$, lung cancer $(n=75)$, prostate cancer $(n=75)$, ovarian cancer $(n=50)$, lymphoma $(n=50)$, glioblastoma $(n=25)$, and melanoma $(n=25)$. As the original TARP-4 database includes only scant data on the expression of immunomarkers expressed by the lymphomas included in the TMA block (http://resresources.nci.nih.gov/tarp/ TARP4.xls) and does not include their final diagnosis, we decided to exclude these cases.

Immunohistochemistry

TMA sections were dried under a low-power ultraviolet light for $120 \mathrm{~min}$. All sections were deparaffinized, rehydrated and subjected to heat-induced antigen retrieval in a water bath, using citrate buffer at $\mathrm{pH} 6.0$ (CK 14 and p63) and $\mathrm{pH} 8.0$ (CK 5/6) for $20 \mathrm{~min}$. Immunohistochemistry according to the streptavidin-biotin-peroxidase complex technique with antibodies against all p63 isoforms (clone 4A4, 1:200; Neomarkers, Freemount, CA, USA), CK 5/6 (clone D5/16B4, 1:200; Zymed, South San Francisco, CA, USA), and CK 14 (clone MCA890H, 1:200; Serotec, 1:10, Oxford, UK) was performed as described elsewhere [37]. Positive (histological sections of a sclerosing papilloma with myoepithelial hyperplasia for p63 and skin for CK 5/6 and CK14) and negative (omission of primary and secondary antibodies) controls were included in each slide run. All controls gave appropriate results.

The distribution of p63, CK 5/6 and CK 14 was independently evaluated by two of the authors (JSRF and AM). All discordant results were resolved in a multi-head microscope. The differential expression of p63, CK 5/6 and CK 14 in normal tissue samples was recorded. p63, CK 5/6 and CK 14 expression in neoplastic samples on the TMA was quantitatively assessed and recorded as: (-) negative; (+) focally positive, up to $25 \%$ of neoplastic cells; or (++) positive, greater than $25 \%$ of the neoplastic cells. Briefly, all neoplastic cells of each TMA core were counted and a ratio between the number of positive cells $\times 100 /$ number of negative cells was calculated.

For statistical analysis, cases were recorded either as (-) or as $(+)$, without semiquantification of the positive cases.

\section{Double immunostaining}

One normal parotid, one minor salivary gland and one normal breast sample were subjected to double immunostaining, as described elsewhere [23], using p63 as first primary antibody and 
either CK 5/6 or CK 14 as second primary antibody. Briefly, the sections were submitted to heat-induced antigen retrieval using a water bath with $10 \mathrm{mM}$ citrate buffer ( $\mathrm{pH}$ 6.0) before incubating for $2 \mathrm{~h}$ at room temperature with the first primary antibody. Then, the sections were sequentially incubated with biotin labeled secondary antibody for $30 \mathrm{~min}$, avidin-biotin-peroxidase complex for $60 \mathrm{~min}$ and $\mathrm{DAB}$ for $5 \mathrm{~min}$. Sections were then sequentially incubated with the second primary antibody for $2 \mathrm{~h}$ at room temperature, goat antimouse IgG for $30 \mathrm{~min}$, alkaline phosphatase mouse anti-alkaline phosphatase for $60 \mathrm{~min}$ and fast-red for $45 \mathrm{~min}$. Controls included (a) omission of the first primary antibody and (b) omission of the second primary antibody.

Statistical analysis

The statistical associations between the distribution of p63, CK 5/6 and CK 14 in different types of neoplasms were evaluated using the $\chi^{2}$ test. We also evaluated whether matched samples of $\mathrm{p} 63$ positive (+) tumors also co-express CK 5/6 and CK 14 more frequently than p63 negative (-) tumors using Fisher's exact test. For statistical analysis, only carcinoma samples were evaluated. The ductal carcinoma in situ (DCIS) sample and the tubular adenoma samples $(n=2)$ were excluded. All tests were two tailed. A 95\% confidence interval was adopted for all tests.

\section{Results}

p63

\section{Normal tissue samples}

Table 1 summarizes the distribution of p63 immunoreactivity in normal tissue samples. Briefly, p63 decorated basal cells of the prostate and of the pseudostratified respiratory epithelium, myoepithelial cells of the bronchial glands and cytotrophoblasts of human placenta (Fig. 1A). Scattered lymphoid cells in the germinal centers were also stained with p63. No endothelial, smooth muscle, neural or adipocytic cells were stained with anti-p63 antibodies in any of the organs examined herein.

\section{Neoplasms}

In the present study, the distribution of p63 immunoreactivity was analyzed in 400 tumors (Table 2). Concerning carcinomas, p63 was consistently expressed in squamous cell carcinomas of the lung (92.6\%) (Fig. 2A),

Table 1 Summary of p63, CK 5/6 and CK 14 distribution in 51 normal tissue samples using tissue array research program (TARP)-4 multi-tumor tissue microarrays. $C K$ cytokeratin, $L / F$ lost/fragmented, $N A$ not available

\begin{tabular}{|c|c|c|c|c|c|c|c|c|c|c|}
\hline Tissue & $n$ & p63 & $\mathrm{L} / \mathrm{F}$ & Note & $\begin{array}{l}\text { CK } \\
5 / 6\end{array}$ & $\mathrm{~L} / \mathrm{F}$ & Note & $\begin{array}{l}\mathrm{Ck} \\
14\end{array}$ & $\mathrm{~L} / \mathrm{F}$ & Note \\
\hline Adrenal & 2 & - & 0 & & + & 0 & & - & 0 & \\
\hline Bladder & 2 & - & 0 & No epithelial cells & + & 1 & Epithelial cells & 1 & 1 & Transitional cells \\
\hline Breast & 5 & - & 2 & Only fat cells & 1 & 4 & $\begin{array}{l}\text { Basal/myoepithelial } \\
\text { cells }\end{array}$ & + & 4 & Basal cells \\
\hline Cerebellum & 1 & - & 0 & & - & 0 & & - & 0 & \\
\hline Esophagus & 2 & NA & 2 & No epithelial cells & + & 1 & Epithelial cells & NA & 2 & \\
\hline Heart & 1 & - & 0 & & NA & 1 & & - & 0 & \\
\hline Kidney & 2 & - & 0 & & - & 1 & & - & 1 & \\
\hline Liver & 3 & - & 0 & & + & 0 & Focal & - & 0 & \\
\hline Lung & 3 & + & 0 & $\begin{array}{l}\text { Basal cells of } \\
\text { respiratory epithelium }\end{array}$ & + & 0 & $\begin{array}{l}\text { Basal cells of } \\
\text { respiratory epithelium }\end{array}$ & + & 2 & $\begin{array}{l}\text { Basal cells of } \\
\text { respiratory epithelium }\end{array}$ \\
\hline Lymph node & 2 & + & 0 & Germinal center cells & - & 0 & & - & 0 & \\
\hline Peripheral nerve & 1 & NA & 1 & & - & 0 & & - & 0 & \\
\hline Placental & 1 & + & 0 & Cytotrophoblast cells & NA & 1 & & NA & 1 & \\
\hline Prostate & 2 & + & 0 & Basal cells & + & 0 & Basal cells of the acini & + & 0 & $\begin{array}{l}\text { Basal cells of the } \\
\text { acini }\end{array}$ \\
\hline Salivary gland & 1 & - & 1 & Severely fragmented & + & 0 & $\begin{array}{l}\text { Basal cells of acini } \\
\text { and intercalated ducts }\end{array}$ & + & 0 & $\begin{array}{l}\text { Basal cells of acini } \\
\text { and intercalated ducts }\end{array}$ \\
\hline Skin & 2 & - & 0 & No keratinocytes & NA & 2 & & NA & 2 & \\
\hline Small bowel & 2 & - & 0 & & - & 0 & & - & 1 & \\
\hline Spleen & 2 & - & 0 & & - & 0 & & - & 0 & \\
\hline Stomach & 1 & NA & 1 & & + & 0 & Parietal cells & - & 0 & \\
\hline Testis & 1 & - & 0 & & - & 0 & & - & 0 & \\
\hline Thyroid & 1 & NA & 1 & & NA & 1 & & NA & 1 & \\
\hline Tongue & 1 & NA & 1 & & NA & 1 & & NA & 1 & \\
\hline
\end{tabular}






Fig. 1 A p63 expression in cytotrophoblasts of a placenta tissue core. B Medium-power magnification of pancreas tissue core: note the presence of scattered cytokeratin 5/6-positive cells. (Streptavi-

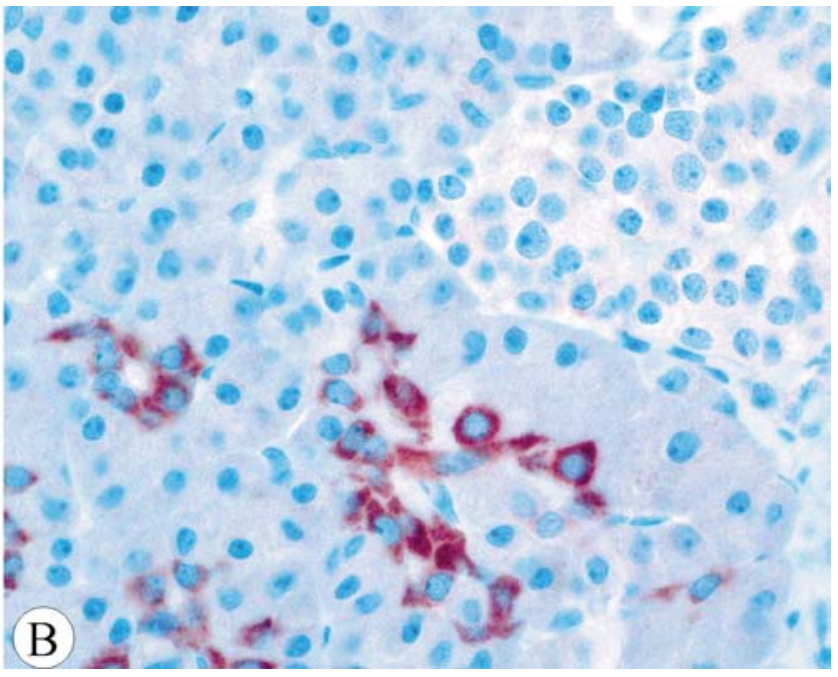

din-biotin-peroxidase/diaminobenzidine; original magnification $\times 200 \mathbf{A}, \mathbf{B}$

ductal carcinoma, ILC invasive lobular carcinoma, $L / F / N$ lost/ fragmented/necrotic, Muc adenoca mucinous adenocarcinoma, N.A. not available, $P D C$ poorly differentiated carcinoma, $S C C$ squamous cell carcinoma, Serous pap serous papillary carcinoma, Tub adeno tubular adenoma
Table 2 Summary of p63, CK 5/6 and CK 14 distribution in 350 carcinomas, 25 malignant melanomas, and 25 glioblastomas using tissue array research program (TARP)-4 multi-tumor tissue microarrays. Adenoca adenocarcinoma, $C C C$ clear cell carcinoma, $C K$ cytokeratin, $C N S$ central nervous system, DCIS ductal carcinoma in situ, Endomet endometrioid carcinoma, IDC invasive

\begin{tabular}{|c|c|c|c|c|c|c|c|c|c|c|c|c|c|}
\hline Tumor samples & $n$ & $\begin{array}{l}\text { p63 } \\
(+)\end{array}$ & $\begin{array}{l}\text { p63 } \\
(++)\end{array}$ & $\mathrm{L} / \mathrm{F} / \mathrm{N}$ & $\begin{array}{l}\text { Total } \\
(\%)\end{array}$ & $\begin{array}{l}\text { CK 5/ } \\
6(+)\end{array}$ & $\begin{array}{l}\text { CK 5/ } \\
6(++)\end{array}$ & $\mathrm{L} / \mathrm{F} / \mathrm{N}$ & $\begin{array}{l}\text { Total } \\
(\%)\end{array}$ & $\begin{array}{l}\mathrm{Ck} \\
14(+)\end{array}$ & $\begin{array}{l}\mathrm{Ck} \\
14(++)\end{array}$ & $\begin{array}{l}\mathrm{L} / \mathrm{F} / \\
\mathrm{N}\end{array}$ & $\begin{array}{l}\text { Total } \\
(\%)\end{array}$ \\
\hline Breast & 75 & 5 & 1 & 7 & 8.8 & 11 & 3 & 12 & 22.2 & 3 & 2 & 13 & 8.1 \\
\hline IDC & 65 & 5 & 1 & 6 & 10.2 & 8 & 3 & 10 & 20.0 & 2 & 2 & 11 & 7.4 \\
\hline ILC & 9 & 0 & 0 & 1 & 0.0 & 2 & 0 & 2 & 28.6 & 0 & 0 & 2 & 0.0 \\
\hline DCIS & 1 & 0 & 0 & 0 & 0.0 & 1 & 0 & 0 & 100.0 & 1 & 0 & 0 & 100.0 \\
\hline Prostate & 75 & 0 & 0 & 6 & 0.0 & 6 & 1 & 11 & 10.9 & 0 & 0 & 11 & 0.0 \\
\hline Adenoca & 75 & 0 & 0 & 6 & 0.0 & 6 & 1 & 11 & 10.9 & 0 & 0 & 11 & 0.0 \\
\hline Lung & 75 & 10 & 20 & 16 & 50.8 & 10 & 23 & 7 & 48.5 & 7 & 11 & 9 & 27.3 \\
\hline Adenoca & 32 & 2 & 2 & 3 & 13.8 & 3 & 0 & 3 & 10.3 & 0 & 0 & 3 & 0.0 \\
\hline PDC & 4 & 0 & 1 & 1 & 33.3 & 1 & 0 & 1 & 33.3 & 0 & 0 & 1 & 0.0 \\
\hline SCC & 39 & 8 & 17 & 12 & 92.6 & 4 & 23 & 3 & 75.0 & 7 & 11 & 5 & 52.9 \\
\hline Colon & 75 & 0 & 1 & 4 & 1.4 & 2 & 1 & 13 & 4.8 & 0 & 0 & 14 & 0.0 \\
\hline Adenoca & 66 & 0 & 1 & 3 & 1.6 & 2 & 1 & 13 & 5.7 & 0 & 0 & 13 & 0.0 \\
\hline Liver met & 1 & 0 & 0 & 0 & 0.0 & 0 & 0 & 0 & 0.0 & 0 & 0 & 0 & 0.0 \\
\hline Muc adenoca & 6 & 0 & 0 & 1 & 0.0 & 0 & 0 & 0 & 0.0 & 0 & 0 & 0 & 0.0 \\
\hline Tub adeno & 2 & 0 & 0 & 0 & 0.0 & 0 & 0 & 0 & 0.0 & 0 & 0 & 1 & 0.0 \\
\hline Ovary & 50 & 5 & 0 & 5 & 11.1 & 6 & 6 & 6 & 27.3 & 4 & 0 & 5 & 8.9 \\
\hline $\mathrm{CCC}$ & 8 & 0 & 0 & 1 & 0.0 & 0 & 1 & 1 & 14.3 & 0 & 0 & 1 & 0.0 \\
\hline Endomet & 5 & 1 & 0 & 1 & 25.0 & 0 & 0 & 2 & 0.0 & 0 & 0 & 1 & 0.0 \\
\hline Muc adenoca & 3 & 0 & 0 & 0 & 0.0 & 0 & 0 & 1 & 0.0 & 0 & 0 & 1 & 0.0 \\
\hline Serous pap & 34 & 4 & 0 & 3 & 12.9 & 6 & 5 & 2 & 34.4 & 4 & 0 & 2 & 12.5 \\
\hline Melanoma & 25 & 2 & 0 & 1 & 8.3 & 1 & 0 & 2 & 4.3 & 0 & 0 & 0 & 0.0 \\
\hline Primary & 20 & 2 & 0 & 0 & 10.0 & 0 & 0 & 0 & 0.0 & 0 & 0 & 0 & 0.0 \\
\hline Metastatic & 5 & 0 & 0 & 1 & 0.0 & 1 & 0 & 2 & 33.3 & 0 & 0 & 0 & 0.0 \\
\hline CNS & 25 & 2 & 1 & 0 & 12.0 & 0 & 0 & 2 & 0.0 & 0 & 0 & 3 & 0.0 \\
\hline Glioblastoma & 25 & 2 & 1 & 0 & 12.0 & 0 & 0 & 2 & 0.0 & 0 & 0 & 3 & 0.0 \\
\hline Total & 400 & 24 & 23 & 39 & 13.0 & 36 & 34 & 53 & 20.2 & 14 & 13 & 55 & 7.8 \\
\hline
\end{tabular}

and was occasionally expressed in ductal carcinomas of the breast (10.2\%) (Fig. 2B), adenocarcinomas (13.8\%) and poorly differentiated carcinomas of the lung (33.3\%), adenocarcinoma of the colon (1.6\%), serous (12.9\%) and endometrioid $(25.0 \%)$ carcinomas of the ovary. Of note, entrapped ducts and acini with p63 + basal cells amidst breast and prostate carcinomas were occasionally observed. p63 also stained $10 \%$ of primary malignant melanomas and $12 \%$ of glioblastomas. 


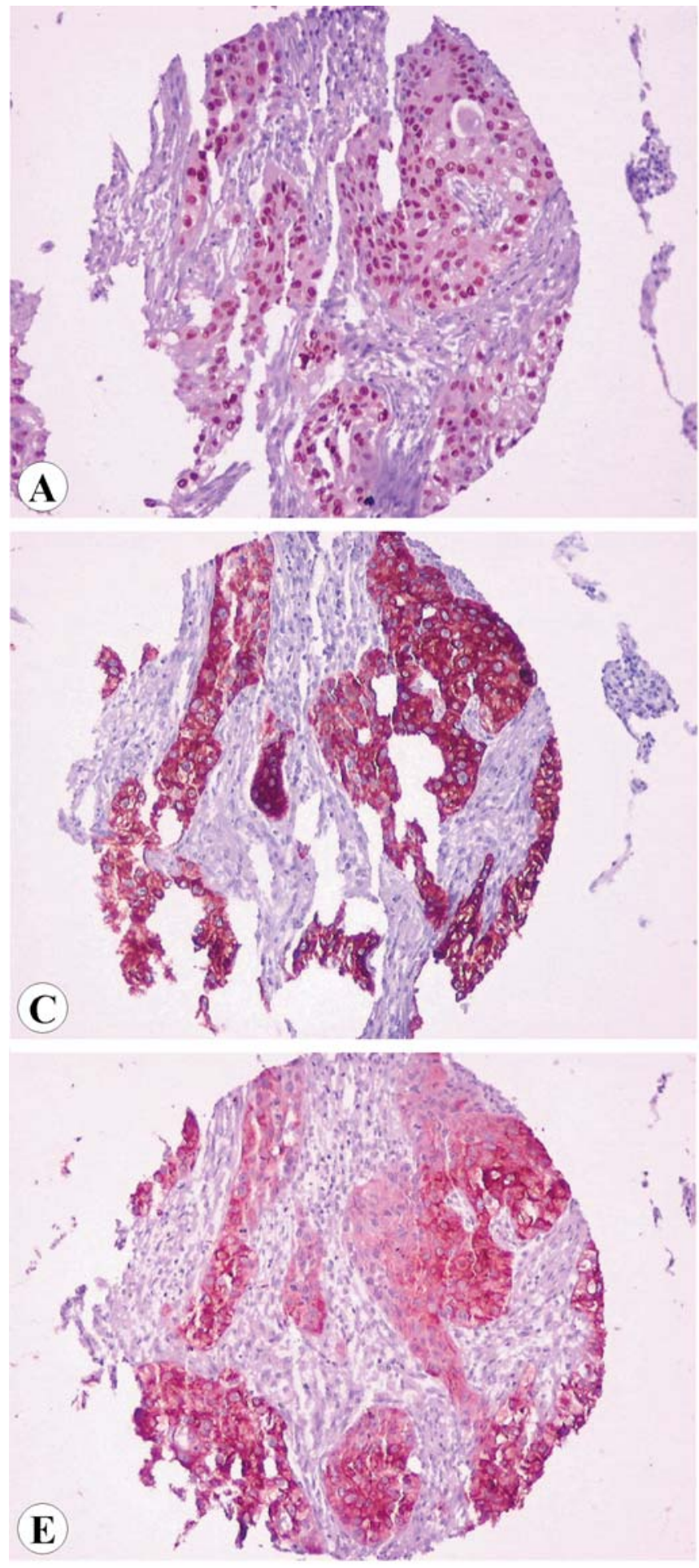

Fig. 2 Tissue microarray samples of a squamous cell carcinoma of the lung $(\mathbf{A}, \mathbf{C}, \mathbf{E})$ and an invasive ductal carcinoma of the breast $(\mathbf{B}, \mathbf{D}, \mathbf{F})$ showing expression of p63 (A, B), CK 5/6 (C, D) and CK

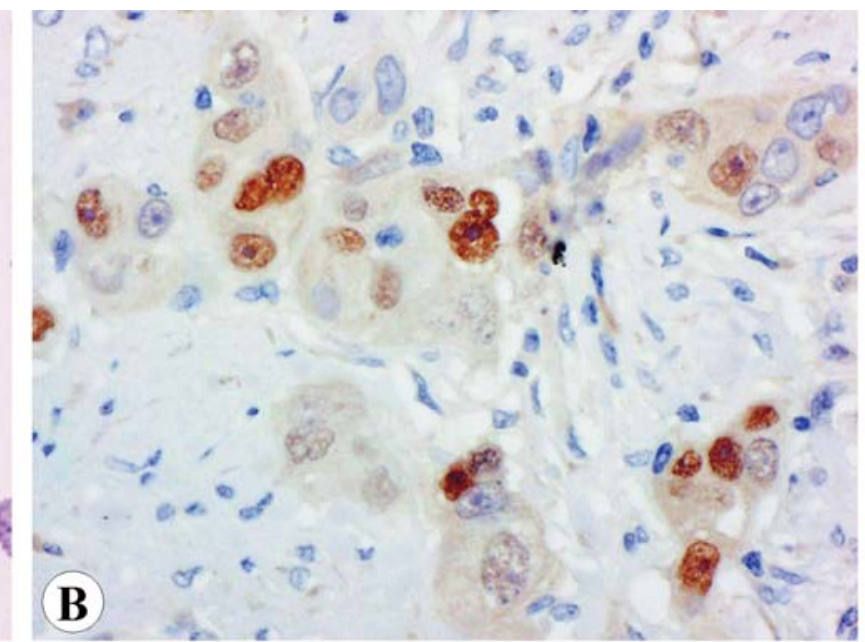

D
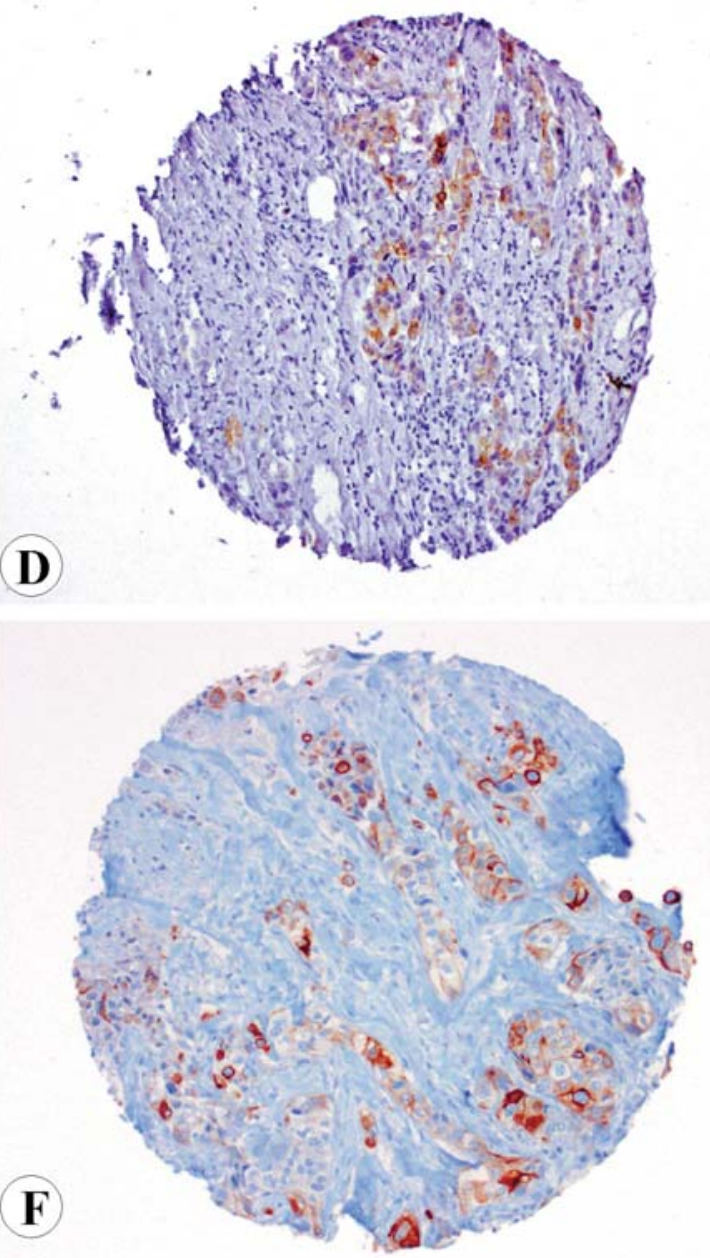

14 (E, F). (Streptavidin-biotin-peroxidase/diaminobenzidine; original magnification $\times 100 \mathbf{A}, \mathbf{C}, \mathbf{D}, \mathbf{E}, \mathbf{F} ; \times 400 \mathbf{B}$ ) 
Cytokeratin 5/6

\section{Normal tissue samples}

CK 5/6 was consistently expressed on the cytoplasm of basal cells of esophageal stratified squamous epithelium and pseudostratified bronchial epithelium; a variable proportion of transitional epithelial cells of the bladder was decorated as well. Myoepithelial cells of the breast and sweat glands, basal cells of prostate acini, and occasional cells lining pancreatic acini (Fig. 1B) showed consistent expression of CK 5/6. Noteworthy, no immunoreactivity was observed in luminal cells of these glands. A faint expression in hepatocytes, adrenocortical cells and gastric parietal cells was also observed. No other epithelial, mesenchymal, lymphoid or neural cell expressed these CKs (Table 1).

\section{Neoplasms}

CK 5/6 consistently decorated squamous cell carcinomas of the lung $(75.0 \%, \mathrm{n}=27)$ (Fig. 2C); conversely, only $10.3 \%$ of primary adenocarcinomas of the lung showed CK 5/6 positivity. In breast carcinoma samples, CK 5/6 expression was observed in $20.0 \%$ of ductal carcinomas $(n=11)$ (Fig. 2D), $28.6 \%$ of lobular carcinomas $(n=2)$, and in the DCIS analyzed herein. Ovarian tumors showed a differential expression of CK 5/6; whereas $34.4 \%$ of serous papillary carcinomas of the ovary $(n=11)$ and $14.3 \%$ of clear cell carcinomas $(n=1)$ expressed CKs 5/6, endometrioid $(n=3)$ and mucinous $(n=2)$ adenocarcinomas were negative. Up to $10 \%$ of prostatic carcinomas $(n=7)$ and $5 \%$ of colonic carcinomas also showed CK 5/6 immunoreactivity. Tubular adenomas $(n=2)$ showed no immunoreactivity for this marker. Interestingly, nonneoplastic breast ducts and prostate acini with CK 5/6 positive basal cells (admixed with breast and prostate carcinomas) were depicted (Table 2).

No non-epithelial neoplasm showed any immunoexpression of CK 5/6 except a case of metastatic malignant melanoma in which $\sim 5 \%$ of the neoplastic cells showed a faint paranuclear staining.

\section{Cytokeratin 14}

\section{Normal tissue samples}

The distribution of CK 14 was very similar to CK 5/6 but for the lack of CK 14-positive cells in pancreatic acini evaluated herein (Table 1). No immunoreactivity in adrenocortical, hepatic or gastric epithelial cells was observed. No mesenchymal, lymphoid or neural cell stained with this antibody.

\section{Neoplasms}

CK 14 expression was observed in 52.9\% of lung squamous cell carcinomas $(n=18)$ (Fig. 2E) and in no lung adenocarcinomas. In the breast, $7.4 \%$ of invasive ductal carcinomas $(n=4)$ (Fig. 2F) and the DCIS expressed CK 14, whereas all seven cases of lobular carcinomas were negative for this intermediate filament. CK 14 also decorated $12.5 \%$ of serous papillary carcinomas $(n=4)$. All other adenocarcinomas were consistently negative. Normal breast ducts and prostate acini with CK $14+$ cells (admixed with breast and prostate carcinomas) were observed. No CK 14 expression was detected in nonepithelial neoplasms (Table 2).

\section{Double immunostaining results}

In salivary glands, p63 consistently decorated basal cells of the excretory and striated ducts, as well as myoepithelial cells of intercalated ducts and serous acini. A slightly lower number of p63-positive cells was observed in seromucinous or mucinous acini. CK 5/6 and CK 14 were consistently expressed in myoepithelial cells of intercalated, striated and excretory ducts and in all types of acini. Noteworthy, some luminal cells showed immunoreactivity for both CK 5/6 and CK 14. Interestingly, basal cells of the ductal system (Fig. 3A and inset) and myoepithelial cells of the acini (Fig. 3B) frequently showed concurrent expression of p63/CK 5/6 and p63/CK 14.

In stratified squamous epithelia, we observed that p63 consistently stained basal cells and a variable proportion of suprabasal cells, but almost no granular or fully differentiated keratinocytes. CK 5/6 showed a similar distribution. CK 14 strongly decorated the basal cell layer, but was also expressed in suprabasal and fully differentiated keratinocytes. Double immunostainings demonstrated concurrent expression of p63/CK 5/6 and p63/CK 14 (Fig. 3C) in basal cells and in some suprabasal cells. Sebaceous glands showed a peculiar distribution of CK 14 and p63; while p63 decorated basal cells of the sebaceous glands, CK 14 preferentially stained fully differentiated sebocytes (Fig. 3C and inset). No sebaceous glands were observed in the sections double-stained for CK $5 / 6$ and p63. In breast lobules, concurrent expression of CK 5/6 and p63 (Fig. 3D), as well as CK 14 and p63 was observed. Occasionally, scattered luminal cells of lobules and ducts were decorated by CK 5/6. No immunoreactivity for p63 or CK 14 was observed in luminal cells.

\section{Statistical analysis}

Squamous cell carcinomas expressed p63 $(P<0.001)$, CK $5 / 6(P<0.001)$ and CK $14(P<0.001)$ more frequently than adenocarcinomas of any site. Also, co-expression of p63/ CK 5/6, p63/CK 14, CK 5/6/CK 14, p63/CK 5/6/CK 14 in matched samples was also more frequently observed in squamous cell carcinomas than in adenocarcinomas 


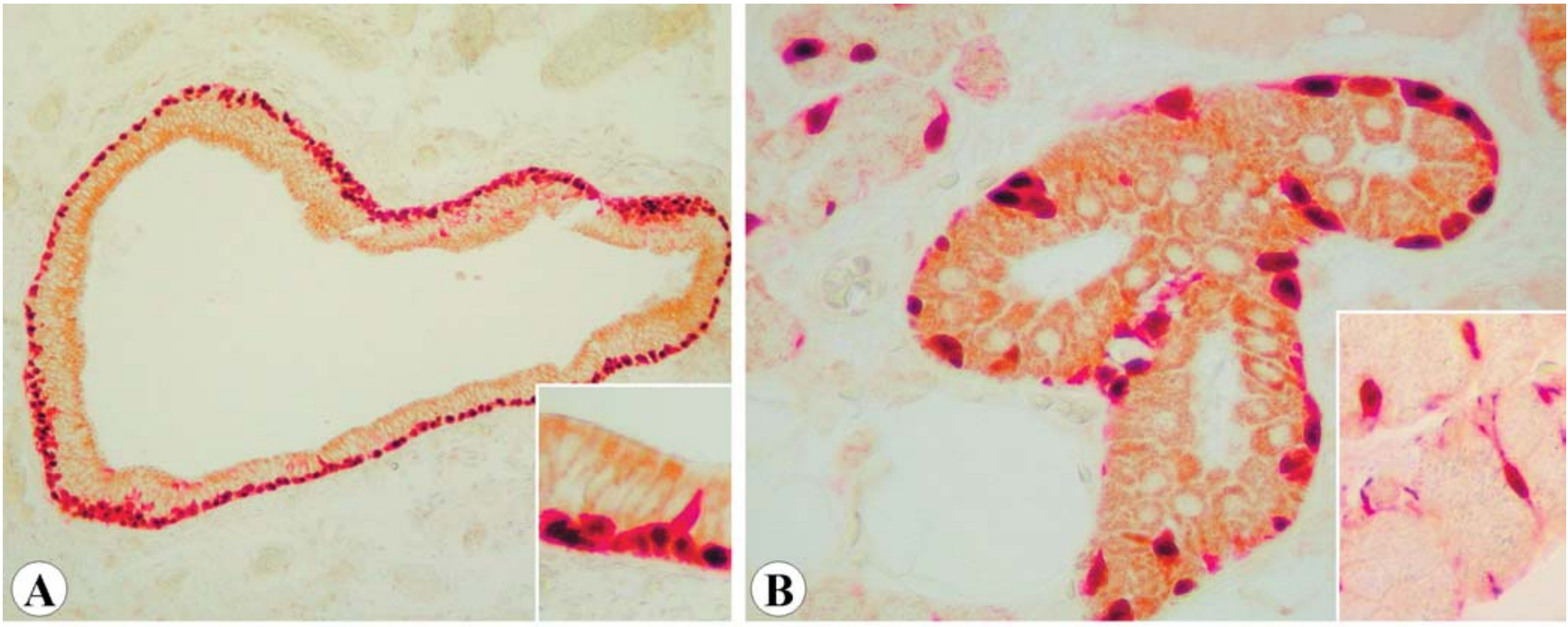

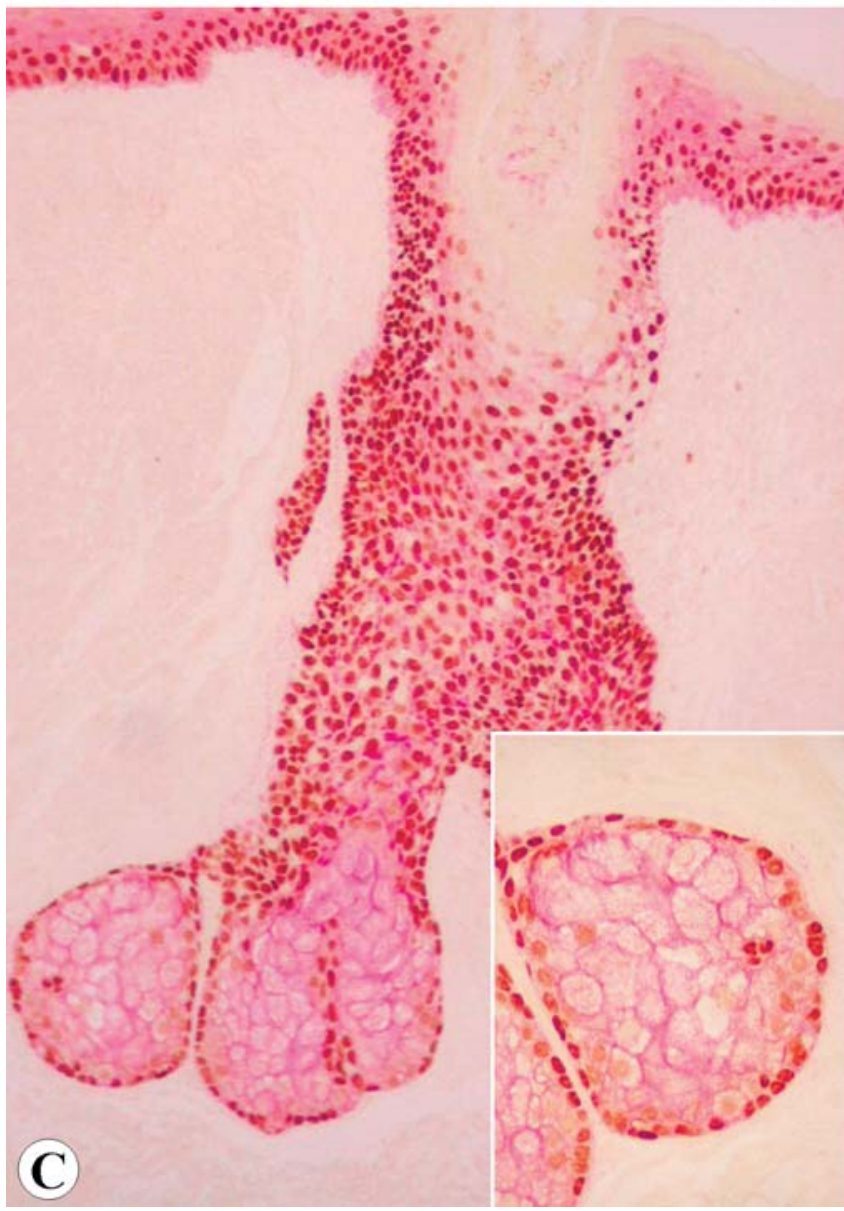

Fig. 3 A p63 (dark-brown)/CK 14 (red) double immunostaining showing concurrent expression of p63 and CK 14 in basal cells of excretory ducts. Inset High-power magnification of excretory duct epithelial cells. Note that only basal cells co-express p63 and CK 14. B Intercalated ducts and acini showing co-expression of p63 (dark-brown) and CK 5/6 (red) in basal and myoepithelial cells, respectively. Inset Myoepithelial cells of serous acini concurrently stained with p63 (dark-brown) and CK 14 (red). C Medium power magnification of the skin stained for p63 (dark-brown) and CK 14 (red). Note the co-expression of p63 and CK 14 in epidermal basal
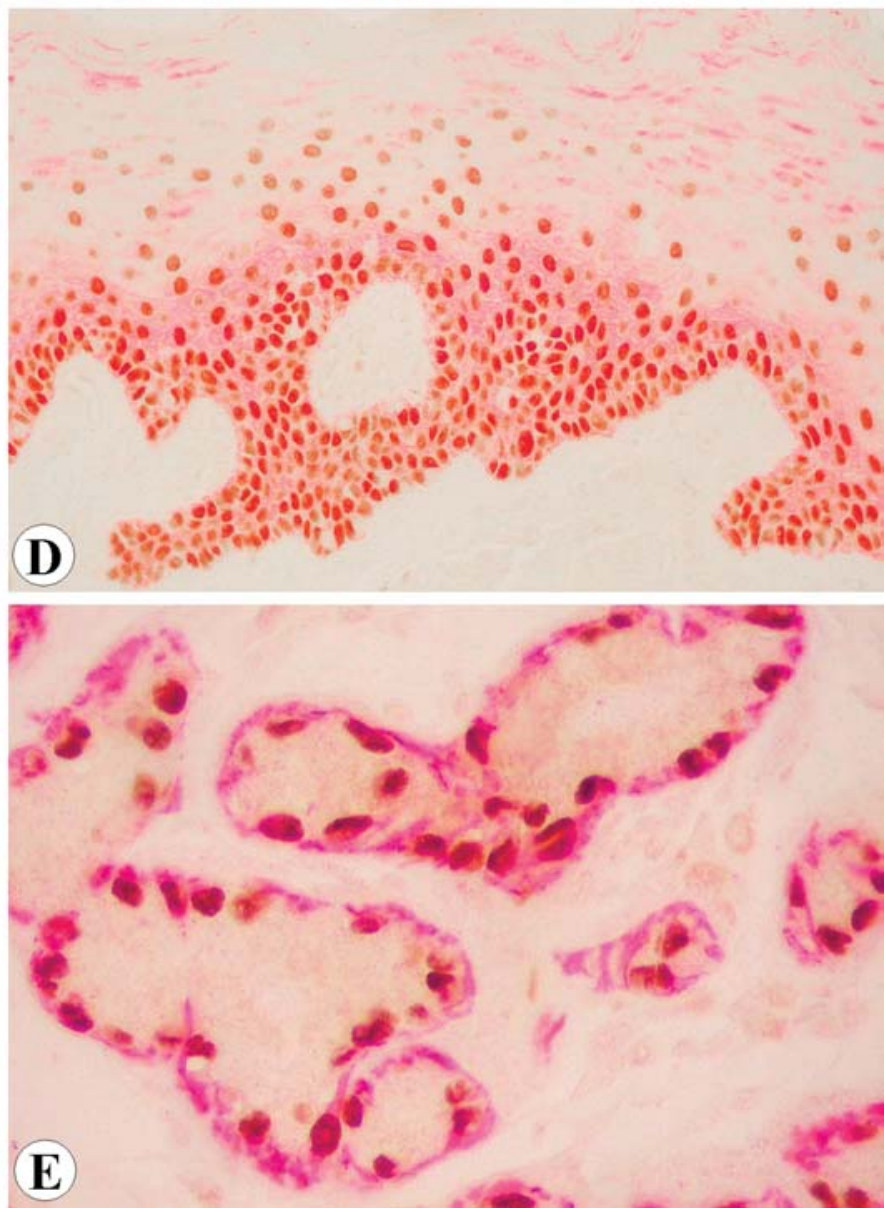

cells and the differential expression of these markers in basal cells of the sebaceous glands and mature sebocytes. Inset High-power magnification of a sebaceous gland. Note that p63 stained basal cells, whereas fully differentiated sebocytes were decorated by CK 14. D Breast lobule showing concurrent expression of p63 (darkbrown) and CK 5/6 (red) in basal/myoepithelial cells. [Streptavidinbiotin-peroxidase-diaminobenzidine (DAB)/alkaline phosphatase anti-alkaline phosphatase (APAAP)-fast red; original magnification $\times 100 \mathbf{A}, \mathbf{C} ; \times 400 \mathbf{A}$ inset, B, B inset, D] 
$(P<0.001$, for all tests). Interestingly, p63 expression showed a statistically significant association with CKs 5/6 and CK 14 expression, irrespective of the histological type (squamous cell carcinoma or adenocarcinoma) of the neoplasm $(P<0.001$, for both tests).

In breast carcinomas, no statistical association between p63, CK 5/6 and CK 14 expression with the histological type (invasive ductal carcinoma vs invasive lobular carcinoma) was observed $(P>0.9999, P=0.6304$, and $P>0.9999$, respectively). Matched tumor samples that expressed p63 also expressed CK 5/6 $(P=0.0002)$, all tumors that expressed CK 14 also expressed CK 5/6 $(P=0.0016)$ and a significant correlation between p63 and CK 14 expression $(P=0.0463)$ was found.

All cases of prostatic carcinomas were usual acinar carcinomas. As the Gleason grade of the whole section of these neoplasms was not provided in the TARP-4 database, we restricted the statistical analysis to the putative co-expression of p63, CK 5/6 and CK 14 in prostate adenocarcinoma matched samples. As no prostate carcinoma analyzed herein expressed p63 or CK 14, no statistical association was found in these neoplasms.

Concerning lung neoplasms, p63, CK 5/6 and CK 14 were more frequently expressed in squamous cell carcinomas than in adenocarcinomas or poorly differentiated carcinomas $(P<0.0001$, all tests $)$. Also, a significant concordant expression of p63 and CK 5/6, p63 and CK 14, CK 5/6 and CK 14 in matched samples was found $(P<0.0001$, all tests). When squamous cell and poorly differentiated carcinomas were excluded, no statistical association between p63, CK 5/6 and CK 14 expression was found.

In colonic carcinomas, no statistical difference was observed between the expression of p63 $(P>0.9999)$ and CKs 5/6 $(P>0.9999)$ in glandular and mucinous adenocarcinomas. No colonic adenocarcinoma expressed CK 14. No statistical correlation was observed between the expression of p63 and CK 14 in matched samples of these neoplasms $(P>0.9999)$.

In ovarian neoplasms, no association was found between the histological type and the expression of p63, CK 5/6 or CK $14(P=0.5455, P=0.3499, P=0.6185)$. No statistical correlation was observed between the expression of p63 and CK 5/6 $(P=0.6077)$, p63 and CK 14 $(P=0.3941)$, and $\mathrm{CK} 5 / 6$ and $\mathrm{CK} 14(P=0.2967)$ in matched samples.

\section{Discussion}

Several studies have reported that $\Delta \mathrm{N}$-p63 isoforms are consistently expressed in the nuclei of basal cells of multilayered epithelia, including skin (epidermis and sebaceous glands), cervical and vaginal mucosa, urothelium, respiratory tract, and prostate, in myoepithelial and basal cells of the breast and sweat glands, as well as in cytotrophoblast of human placenta $[1,5,10,11,12,22$, 24, 27, 30, 31, 32, 33, 34, 35, 36, 37, 39, 43, 47]. Analysis of p63-/- mice demonstrated that these mice present with truncated limbs and have no hair follicles, teeth, mammary, lachrymal or salivary glands [22, 24, 47]. Moreover, squamous epithelia of p63-/- mice (i.e., squamous epithelia of skin and tongue) failed to develop the spinosum, granulosum and stratum corneum and to correctly express CK 5 and CK 14 [22, 24, 47]. We demonstrated that in salivary glands, p63 has a preferential expression in basal/myoepithelial cells of the intercalated, striated and excretory ducts, as well as in myoepithelial cells of serous acini. A smaller proportion of p63 positive myoepithelial cells was observed in mucinous and seromucinous acini when compared with parotid gland serous acini.

It has been demonstrated that anti-p63 antibodies decorate the majority of squamous cell carcinomas $[5,11$, $12,19,32,36]$, basal cell carcinomas of the skin $[11,36]$, transitional cell carcinomas [11, 19, 32], and tumors with myoepithelial differentiation of the breast [32, 33, 38, 45] and lungs [30]. Our study confirmed and expanded the results of previously published studies that have demonstrated p63 expression in almost all squamous cell carcinomas $[5,11,12,14,19,30,31,43]$ and in a minor proportion of ductal carcinomas of breast (4.6-11\%) [1, 27]. Also, we observed that some serous and endometrioid carcinomas of the ovary and rare adenocarcinomas of the colon express this marker.

Developmental analysis of p63 knockout mice has demonstrated that the expression of CK 5 and CK 14 is somehow controlled by p63 [22, 24, 47]. This is not striking, as in vitro studies using transformed human keratinocytes have shown that p63 is a nuclear transcription factor that triggers the expression of keratinocytic differentiation markers (i.e., involucrin and loricrin) [10, 22]. Conversely, when terminal differentiation is achieved or triggered by other mechanisms, such as high calcium exposure, there is a downregulation of all p63 isoforms [10]. These data are in accordance with previous publications showing that p63 is expressed in squamous cell carcinomas $[5,11,12,14,19,31]$; however, terminally differentiated cells, such as those observed in the center of squamous pearls, are negative for this marker [36].

In the present study, we demonstrated a concurrent expression of p63, CK 5/6 and CK 14 in $6.54 \%$ of human carcinoma matched samples (18 of 275 carcinomas in which all three samples from each neoplasm could be unequivocally evaluated and none of them were necrotic, fragmented or lost during immunohistochemical staining). In adenocarcinomas, this triple concurrent expression in matched samples was only observed in two invasive ductal carcinomas of the breast. All the other 16 cases were lung squamous cell carcinomas (25 of the 39 squamous cell carcinoma samples were unequivocally evaluated for all markers and none of them were necrotic, fragmented or lost during immunohistochemical procedure). Our findings suggest that these markers may be reliably used for the diagnosis of squamous cell carcinomas and also indicate that some breast carcinomas coexpress these markers. 
Table 3 Summary of previously reported studies on p63, CK 5/6 and CK 14 distribution in large series of neoplasms (adenocarcinomas and squamous cell carcinomas) $[1,2,5,6,7,8,9,11,12,13$,
$14,18,19,27,28,29,31,36,42,43,44,46]$ and in the present study using tissue array research program (TARP)-4 multi-tumor tissue microarray

\begin{tabular}{|c|c|c|c|c|c|c|}
\hline \multirow[t]{2}{*}{ Marker tumor } & \multicolumn{2}{|l|}{ p63 } & \multicolumn{2}{|l|}{ CKs 5/6 } & \multicolumn{2}{|l|}{ CK 14} \\
\hline & $\begin{array}{l}\text { Previous studies } \\
\text { (Range, mean \%) }\end{array}$ & $\begin{array}{l}\text { Current } \\
n(\%)\end{array}$ & $\begin{array}{l}\text { Previous studies } \\
\text { (Range, mean \%) }\end{array}$ & $\begin{array}{l}\text { Current } \\
n(\%)\end{array}$ & $\begin{array}{l}\text { Previous study } \\
\text { (Range, mean \%) }\end{array}$ & $\begin{array}{l}\text { Current } \\
n(\%)\end{array}$ \\
\hline Breast* & $14 / 337(0-11,4)$ & $6 / 67(8.9)$ & $29 / 110(5-61,26)$ & $14 / 62(22.6)$ & $3 / 104(0-4,3)$ & $5 / 62(8.1)$ \\
\hline Prostate & $26 / 437(0-13,6)$ & $0 / 69(0)$ & $0 / 46(0-0,0)$ & $7 / 64(10.9)$ & $0 / 18(0)$ & $0 / 64(0)$ \\
\hline Lung** & $21 / 156(0-50,13)$ & $4 / 29(13.8)$ & $6 / 82(0-33,7)$ & $3 / 29(10.3)$ & $2 / 11(18.2)$ & $0 / 29(0)$ \\
\hline Colon & $1 / 22(0-8,4.5)$ & $1 / 69(1.4)$ & $4 / 53(0-30,7.5)$ & $3 / 60(5)$ & $1 / 20(5)$ & $0 / 61(0)$ \\
\hline Ovary & $3 / 32(6-13,9)$ & $5 / 45(11.1)$ & $22 / 75(17-33,29)$ & $12 / 44(27.3)$ & $3 / 24(12.5)$ & $4 / 45(8.9)$ \\
\hline Squamous cell carcinoma & $221 / 247(75-100,89)$ & $25 / 27(92.6)$ & $86 / 98(84-100,88)$ & $27 / 36(75)$ & $13 / 15(87)$ & $18 / 34(53.0)$ \\
\hline
\end{tabular}

*Only usual types and usual variants of invasive breast carcinomas were included in this meta-analyses

**Adenocarcinomas and bronchioalveolar carcinomas were included in this category. Adenosquamous carcinomas were included in the squamous cell carcinoma, because p63 expression was restricted to those areas with squamous differentiation

It has been described that up to $18 \%$ of breast carcinomas may show a partial or complete basal/ myoepithelial phenotype [17, 18, 21]. Our double immunohistochemical preparations demonstrated concurrent expression of p63 and CK 5/6, as well as p63 and CK 14 in a subset of basal cells of breast lobules and ducts. Also, we have already described a concurrent expression of p63, p-cadherin, maspin, alpha smooth muscle actin , and CK 14 in a subset of metaplastic carcinomas of the breast (tumors with putative basal/myoepithelial differentiation) [37]. In the present study, 2 of 56 (3.57\%) invasive breast carcinomas samples that were unequivocally evaluated for p63, CK 5/6 and CK 14 co-expressed all of these markers, reiterating that a subset of breast carcinomas may show a basal/myoepithelial phenotype $[17,18,21]$.

Multi-tumor TMAs have previously been used to screen different tumor types for molecular alterations of interest $[3,11,15,16,20,25,41,48]$. We described herein another application of multi-tumor TMAs: to screen the distribution of immunohistochemical markers used for diagnostic purposes in a plethora of tumor types. The results of TMAs composed of a single $0.6-\mathrm{mm}$ core of each tumor are disputable; while some authors have demonstrated that results from this sort of array have demonstrated $97-98 \%$ concordance with results observed in whole tissue sections for estrogen receptor, progesterone receptor and c-erbB-2 [48], others have claimed that arrays composed of a single $0.6 \mathrm{~mm}$ core would not cover and represent the heterogeneity of human neoplasms [16]. This issue is even more important regarding markers that are usually focally expressed in selected types of human neoplasms, such as p63 and basal keratins in breast carcinomas [1, 41]. Recently, validation studies of TMAs have demonstrated that even for heterogeneously expressed markers, one single core can match the staining pattern of an entire section more than $90 \%$ of the time and that full section cut-off values may also be applied when scoring TMAs [4, 15, 48]. Although we have not compared our TMA data with whole histological sections of the same tumors, our results are in accordance with previously reported series on p63 $[1,5,12,14,18,19,27$,
29, 31, 36, 43, 44, 47], CKs 5/6 [2, 6, 9, 13, 19, 28, 42] and CK $14[7,8,13]$ distribution (Table 3).

In conclusion, we described the expression of p63, CKs 5/6 and CK 14 in 350 carcinomas, 25 malignant melanomas, and 25 glioblastomas using serial sections of TARP-4 multi-tumor TMA. Regardless of the small-sized samples included in the TMA, our results are in accordance with previous studies performed on whole histological sections $[1,2,5,6,7,8,9,12,13,14,18,19,27$, $28,29,31,36,42,43,44,46]$ and showed only minor discrepancy with a similar study that was also performed on TMAs [11], suggesting that TMAs can be used to describe the distribution of antibodies that might be used as diagnostic markers. Moreover, our results also corroborate that p63, CKs 5/6 and CK 14 may be used as adjunct antibodies for the pathologic recognition of squamous cell carcinomas $[6,7,8,11,19,31,47]$. In addition, we also demonstrated that a subset of breast carcinomas express these markers [1, 17, 18, 32, 33, 37], and that this might reflect a basal or an intermediary phenotype [18, 21], despite their unremarkable morphology.

Acknowledgements This study was partially supported by a Ph.D. grant from the Portuguese Science and Technology Foundation [Fundação para a Ciência e a Tecnologia (FCT)-Ministério da Ciência e Tecnologia (MCT)—Portugal], reference SFRH/BD/ 5386/2001. Reis Filho J.S. is an FCT Ph.D. student and is the recipient of the Gordon Signy Foreign Fellowship Award, 2001, from the World Association of Societies of Pathology and Laboratory Medicine. The authors thank Dr. Andrew Folpe for his insightful comments on the manuscript and Mrs. Athely Guedes for preparing the manuscript for submission.

\section{References}

1. Barbareschi M, Pecciarini L, Cangi MG, Macri E, Rizzo A, Viale G, Doglioni C (2001) p63, a p53 homologue, is a selective nuclear marker of myoepithelial cells of the human breast. Am J Surg Pathol 25:1054-1060

2. Bocker W, Moll R, Poremba C, Holland R, Van Diest PJ, Dervan P, Burger H, Wai D, Ina Diallo R, Brandt B, Herbst H, Schmidt A, Lerch MM, Buchwallow IB (2002) Common adult stem cells in the human breast give rise to glandular and myoepithelial cell lineages: a new cell biological concept. Lab Invest 82:737-746 
3. Bubendorf L, Nocito A, Moch H, Sauter G (2001) Tissue microarray (TMA) technology: miniaturized pathology archives for high-throughput in situ studies. J Pathol 195:72-79

4. Camp RL, Charette LA, Rimm DL (2000) Validation of tissue microarray technology in breast carcinoma. Lab Invest 80:1943-1999

5. Choi HR, Batsakis JG, Zhan F, Sturgis E, Luna MA, El-Naggar AK (2002) Differential expression of p53 gene family members p63 and p73 in head and neck squamous tumorigenesis. Hum Pathol 33:158-164

6. Chu PG, Weiss LM (2002) Expression of cytokeratin 5/6 in epithelial neoplasms: an immunohistochemical study of 509 cases. Mod Pathol 15:6-10

7. Chu PG, Weiss LM (2002) Keratin expression in human tissues and neoplasms. Histopathology 40:403-439

8. Chu PG, Lyda MH, Weiss LM (2001) Cytokeratin 14 expression in epithelial neoplasms: a survey of 435 cases with emphasis on its value in differentiating squamous cell carcinomas from other epithelial neoplasms. Histopathology 39:9-16

9. Cury PM, Butcher DN, Fisher C, Corrin B, Nicholson AG (2000) Value of the mesothelium-associated antibodies thrombomodulin, cytokeratin 5/6, calretinin, and cd44 h in distinguishing epithelioid pleural mesothelioma from adenocarcinoma metastatic to the pleura. Mod Pathol 13:107-112

10. De Laurenzi V, Rossi A, Terrinoni A, Barcaroli D, Levrero M, Costanzo A, Knight RA, Guerrieri P, Melino G (2000) p63 and p73 transactivate differentiation gene promoters in human keratinocytes. Biochem Biophys Res Commun 273:342-346

11. Di Como CJ, Urist MJ, Babayan I, Drobnjak M, Hedvat CV, Teruya-Feldstein J, Pohar K, Hoos A, Cordon-Cardo C (2002) p63 expression profiles in human normal and tumor tissues. Clin Cancer Res 8:494-501

12. Glickman JN, Yang A, Shahsafaei A, McKeon F, Odze RD (2001) Expression of p53-related protein p63 in the gastrointestinal tract and in esophageal metaplastic and neoplastic disorders. Hum Pathol 32:1157-1165

13. Heatley M, Maxwell P, Whiteside C, Toner P (1995) Cytokeratin intermediate filament expression in benign and malignant breast disease. J Clin Pathol 48:26-32

14. Hibi K, Trink B, Patturajan M, Westra WH, Caballero OL, Hill DE, Ratovitski EA, Jen J, Sidransky D (2000) AIS is an oncogene amplified in squamous cell carcinoma. Proc Natl Acad Sci U S A 97:5462-5467

15. Hoos A, Cordon-Cardo C (2001) Tissue microarray profiling of cancer specimens and cell lines: opportunities and limitations. Lab Invest 81:1331-1338

16. Hoos A, Urist MJ, Stojadinovic A, Mastorides S, Dudas ME, Leung DH, Kuo D, Brennan MF, Lewis JJ, Cordon-Cardo C (2001) Validation of tissue microarrays for immunohistochemical profiling of cancer specimens using the example of human fibroblastic tumors. Am J Pathol 158:1245-1251

17. Jones C, Foschini MP, Chaggar R, Lu YJ, Wells D, Shipley JM, Eusebi V, Lakhani SR (2000) Comparative genomic hybridization analysis of myoepithelial carcinoma of the breast. Lab Invest 80:831-836

18. Jones C, Nonni AV, Fulford L, Merrett S, Chaggar R, Eusebi V, Lakhani SR (2001) CGH analysis of ductal carcinoma of the breast with basaloid/myoepithelial cell differentiation. $\mathrm{Br} \mathrm{J}$ Cancer 85:422-427

19. Kaufmann O, Fietze E, Mengs J, Dietel M (2001) Value of p63 and cytokeratin $5 / 6$ as immunohistochemical markers for the differential diagnosis of poorly differentiated and undifferentiated carcinomas. Am J Clin Pathol 116:823-830

20. Lakhani SR, Ashworth A (2001) Microarray and histopathological analysis of tumours: the future and the past? Nat Rev Cancer 1:151-157

21. Lakhani SR, O'Hare MJ (2001) The mammary myoepithelial cell-Cinderella or ugly sister? Breast Cancer Res 3:1-4

22. Levrero M, De Laurenzi V, Costanzo A, Gong J, Wang JY, Melino G (2000) The p53/p63/p73 family of transcription factors: overlapping and distinct functions. J Cell Sci 113:1661-1670
23. Lopes JM, Nesland JM, Reis-Filho JS, Holm R (2002) Differential Ki67 and bcl-2 immunoexpression in solid-glandular and spindle cell components of biphasic synovial sarcoma: a double immunostaining assessment with cytokeratin and vimentin. Histopathology 40:464-471

24. Mills AA, Zheng B, Wang XJ, Vogel H, Roop DR, Bradley A (1999) p63 is a p53 homologue required for limb and epidermal morphogenesis. Nature 398:708-713

25. Moch H, Kononen J, Kallioniemi OP, Sauter G (2001) Tissue microarrays: what will they bring to molecular and anatomic pathology? Adv Anat Pathol 8:14-20

26. Moll R, Franke WW, Schiller DL, Geiger B, Krepler R (1982) The catalog of human cytokeratins: patterns of expression in normal epithelia, tumors and cultured cells. Cell 31:11-24

27. O'Connell JT, Mutter GL, Cviko A, Nucci M, Quade BJ, Kozakewich HP, Neffen E, Sun D, Yang A, McKeon FD, Crum CP (2001) Identification of a basal/reserve cell immunophenotype in benign and neoplastic endometrium: a study with the p53 homologue p63. Gynecol Oncol 80:30-36

28. Ordóñes NG (1998) Value of cytokeratin 5/6 immunostaining in distinguishing epithelial mesothelioma of the pleura from lung adenocarcinoma. Am J Surg Pathol 22:1215-1221

29. Parsons JK, Gage WR, Nelson WG, De Marzo AM (2001) p63 protein expression is rare in prostate adenocarcinoma: implications for cancer diagnosis and carcinogenesis. Urology 58:619-624

30. Pelosi G, Fraggetta F, Maffini F, Solli P, Cavallon A, Viale G (2001) Pulmonary epithelial-myoepithelial tumor of unproven malignant potential: report of a case and review of the literature. Mod Pathol 14:521-526

31. Pelosi G, Pasini F, Stenholm CO, Pastorino U, Maisonneuve P, Sonzogni A, Maffini F, Pruneri G, Fraggetta F, Cavallon A, Roz E, Iannucci A, Bresaola E, Viale G (2002) p63 immunoreactivity in lung cancer: yet another player in the development of squamous cell carcinomas? J Pathol 198:100-109

32. Reis-Filho JS, Schmitt FC (2002) Taking advantage of basic research: p63 is a reliable myoepithelial and stem cell marker. Adv Anat Pathol 9:280-289

33. Reis Filho JS, Schmitt FC (2003) p63 expression in sarcomatoid/metaplastic carcinomas of the breast. Histopathology 42:94-95

34. Reis Filho JS, Albergaria A, Milanezi F, Amendoeira I, Schmitt FC (2002) Naked nuclei revisited: p63 immunoexpression. Diagn Cytopathol 27:135-138

35. Reis Filho JS, Milanezi F, Albergaria A, Amendoeira I, Schmitt FC (2002) p63 staining of myoepithelial cells in breast fine needle aspirates: a study of its role in differentiating in situ from invasive ductal carcinomas of the breast. J Clin Pathol 55:936-939

36. Reis-Filho JS, Torio B, Albergaria A, Schmitt FC (2002) p63 expression in normal skin and usual skin carcinomas. J Cutan Pathol 29:517-523

37. Reis-Filho JS, Milanezi F, Paredes J, Silva P, Pereira EM, Maeda AS, de Carvalho LV, Schmitt FC (2003) Novel and classic myoepithelial/stem cell markers in metaplastic carcinomas of the breast. Appl Immunohistochem Mol Morphol 11:18

38. Romano V, Bosco P, Rocchi M, Costa G, Leube RE, Franke WW, Romeo G (1988) Chromosomal assignments of human type I and type II cytokeratin genes to different chromosomes. Cytogenet Cell Genet 48:148-151

39. Signoretti S, Waltregny D, Dilks J, Isaac B, Lin D, Garraway L, Yang A, Montironi R, McKeon F, Loda M (2000) p63 is a prostate basal cell marker and is required for prostate development. Am J Pathol 157:1769-1775

40. Tot T (2002) Cytokeratins 20 and 7 as biomarkers: usefulness in discriminating primary from metastatic adenocarcinoma. Eur J Cancer 38:758-763

41. van de Rijn M, Perou CM, Tibshirani R, Haas P, Kallioniemi O, Kononen J, Torhorst J, Sauter G, Zuber M, Kochli OR, Mross F, Dieterich H, Seitz R, Ross D, Botstein D, Brown P (2002) Expression of cytokeratins 17 and 5 identifies a group of breast 
carcinomas with poor clinical outcome. Am J Pathol 161:19911996

42. Vlasoff DM, Baschinsky DY, Frankel WL (2002) Cytokeratin $5 / 6$ immunostaining in hepatobiliary and pancreatic neoplasms. Appl Immunohistochem Mol Morphol 10:147-151

43. Wang BY, Gil J, Kaufman D, Gan L, Kohtz DS, Burstein DE (2002) p63 In pulmonary epithelium, pulmonary squamous neoplasms, and other pulmonary tumors. Hum Pathol 33:921926

44. Wang TY, Chen BF, Yang YC, Chen H, Wang Y, Cviko A, Quade BJ, Sun D, Yang A, McKeon FD, Crum CP (2001) Histologic and immunophenotypic classification of cervical carcinomas by expression of the p53 homologue p63: a study of 250 cases. Hum Pathol 32:479-486

45. Wang X, Mori I, Tang W, Yang Q, Nakamura M, Nakamura Y, Sato M, Sakurai T, Kennichi K (2001) Metaplastic carcinoma of the breast: p53 analysis identified the same point mutation in the three histologic components. Mod Pathol 14:1183-1186

46. Weber A, Bellmann U, Bootz F, Wittekind C, Tannapfel A (2002) Expression of p53 and its homologues in primary and recurrent squamous cell carcinomas of the head and neck. Int $\mathrm{J}$ Cancer 99:22-28

47. Yang A, Schweitzer R, Sun D, Kaghad M, Walker N, Bronson RT, Tabin C, Sharpe A, Caput D, Crum C, McKeon F (1999) p63 is essential for regenerative proliferation in limb, craniofacial and epithelial development. Nature 398:714-718

48. Zhang D, Salto-Tellez M, Putti TC, Do E, Koay ES (2003) Reliability of tissue microarrays in detecting protein expression and gene amplification in breast cancer. Mod Pathol 16:79-85 